\title{
INFLUENCE OF ORGANISATIONAL FACTORS ON THE IMPLEMENTATION OF PHYSICAL EDUCATION IN EUROPEAN TERTIARY INSTITUTIONS
}

Robert Podstawski

University of Warmia and Mazury in Olsztyn, Poland

E-mail: podstawskirobert@gmail.com

Krzysztof Borysławski

Wrocław University of Life and Environmental Sciences, Poland

E-mail: krzysztof.boryslawski@upwr.edu.pl

Marta Zurawik

Independent Researcher, United Kingdom

E-mail: martazurawik@hotmail.com

\begin{abstract}
Alena Bukova
Pavol Jozef Šafárik University in Košice, Slovak Republic

E-mail: alena.bukova@upjs.sk

Bojan Masanovic

University of Montenegro, Montenegro

E-mail: bojan.masanovic@ucg.ac.me
\end{abstract}

Ferenc Ihasz

Eötvös Lóránd University, Hungary E-mail: ihasz.ferenc@ppk.elte.hu

Miloš Marković

University of Belgrade, Serbia

E-mail: miloscj@gmail.com

Aneta Omelan

University of Warmia and Mazury in Olsztyn, Poland

E-mail: aneta.omelan@uwm.edu.pl

\begin{abstract}
The purpose of higher education is to produce active and intellectually well-rounded individuals yet, the transition to higher education seems to have deleterious effects on university and college students' (UCS) fitness levels and physical activity (PA).

The aim of this quantitative research was to analyse the influences of organisational factors on the implementation of physical education (PE) among UCS in European tertiary institutions. A purposive sampling method was employed. Seven academic peers gathered information on characteristics of
\end{abstract}


Robert PODSTAWSKI, Krzysztof BORYSŁAWSKI, Marta ZURAWIK, Alena BUKOVA, Bojan MASANOVIC, Ferenc IHASZ, Miloš MARKOVIĆ, Aneta OMELAN. Influence of organisational factors on the implementation of physical education in European tertiary institutions

PROBLEMS

OF EDUCATION IN THE $21^{\text {st }}$ CENTURY Vol. 78 , No. 6, 2020

1028

tertiary institutions, sport and leisure facilities, types and characteristics of PA programs available for UCS in 66 European tertiary institutions.

The results suggested that the curricula requirements for PE in public tertiary institutions were similar to private establishments, with minor administrative variations. Public tertiary institutions had significantly higher number of PE hours and PE sessions per semester, PE minutes per academic hour, duration of PE session, number PE teachers and number of students per one PE teacher. Universities had significantly higher number of PE semesters, PE minutes per academic hour, and hired more PE teachers. The organizational differences between public and private institutions might be explained by a lack of clear guidelines regarding PE curricula in higher education across European countries, and greater autonomy of the private tertiary institutions. Moreover, PA programs in higher education adhere to minimum requirements of the syllabi, which restrict total amounts of PE among UCS. Thus, it is recommended PE classes should become obligatory, with extended hours, appropriately qualified teachers and improved financing.

Keywords: higher education, university college students (UCS), physical education, European tertiary institutions, PE curriculum, organisational factors

\section{Introduction}

In recent decades, the changes in lifestyle from active to sedentary have replaced the traditional daily physical activities with the activities that reduce energy expenditure. The decrease in daily levels of physical activity (PA) of the contemporary lifestyles have significantly reduced daily demand for PA in general populations and is responsible for civilisation diseases related to inactive behaviours (Keating et al., 2005; Saelens et al., 2003). Furthermore, the prevalence of inactivity in leisure time varies with cultural and economic developmental factors, averaging 23\% in North-Western Europe and the United States, 30\% in Central and Eastern Europe, 39\% in Mediterranean, 42\% in Pacific Asian, and 44\% in developing countries. Correspondingly, the likelihood of leisure-time PA is positively associated with the strength of beliefs in the health benefits of activity and with national economic development (per capita GDP) (Haase et al., 2004).

The sedentary behaviours are also prevalent among university and college students (UCS) around the world, and for the majority of them, the amount of PA required while performing daily activities is no longer sufficient for maintaining sound fitness (Lipošek et al., 2018). Regular participation in PA is an important contributor to a healthy lifestyle and it can provide immediate and future health benefits (Hilland et al., 2009). Therefore, comprehensive PA guidelines have been developed to encourage participation. The main recommendation is that young adults engage in at least 60 minutes of moderate to vigorous PA every day (Garber et al., 2011). The minimum recommended amount of PA for individuals aged 18 to 65 is $\geq 30$ $\mathrm{min} /$ day of moderate-intensity endurance training performed 5 days per week ( $\geq 150 \mathrm{~min} / \mathrm{week}$ ) or $\geq 25$ min of high-intensity endurance training performed 3 days per week ( $\geq 75 \mathrm{~min} / \mathrm{week}$ ). Moderate- and high-intensity training can also be combined in the effort range of $\geq 500-1000$ MET. Resistance, balance, agility and coordination training targeting each muscle group is recommended 2-3 days per week, and stretching exercises (60s) are recommended 2 days per week (Haskell et al., 2007).

The scientific evidence from around the world suggests that UCS do not engage enough in PA and show low levels of fitness. For instance, American College Health Association (2007) reported that $44.2 \%$ of American students exercised vigorously for at least 20 minutes or moderately for at least 30 minutes, at least 3 out of the past 7 days, and $47.7 \%$ of students reported that they exercised to strengthen or tone muscles at least 2 out of the past 7 days. Similar research study was conducted in Europe by Steptoe et al. (1997) who reported that among UCS from 21 European countries age-adjusted prevalence of physical exercise in the past 2 weeks averaged $73.2 \%$ among men and $68.3 \%$ among women, but varied significantly 
Robert PODSTAWSKI, Krzysztof BORYSŁAWSKI, Marta ZURAWIK, Alena BUKOVA, Bojan MASANOVIC, Ferenc IHASZ, Miloš MARKOVIĆ, Aneta OMELAN. Influence of organisational factors on the implementation of physical education in European tertiary institutions

from more than $80 \%$ to less than $60 \%$ across country samples. Furthermore, several research studies conducted in Europe reported low PA levels among Romanian (Fagaras et al., 2015), Polish (Podstawski et al., 2014) and Spanish (Martinez-Lemos et al., 2012) students.

Supplementary evidence suggests that many UCS do not meet the above recommendations in the process of transitioning from adolescence to adulthood (Kim \& Cardinal, 2017; Sigmundova et al., 2013). University students who begin to live independently experience changes in lifestyle habits, attitudes and social roles. The research showed that only onethird of UCS who was active in high school became insufficiently active upon transitioning to university life (Bray \& Born, 2004; Li et al., 2009). The transition to higher education seems to have deleterious effects on students' PA behaviour and motivation, which lead to a significantly decline in their fitness levels (Fagaras et al., 2015; Kwan et al., 2012; Podstawski et al., 2013). Furthermore, it is also worth noting that PA behaviours of UCS tend to have a long-term impact on adult PA habits (Keating et al., 2005) since PA patterns established in college/university are likely to be maintained for a long time (Corbin, 2002; Sparling \& Snow, 2002).

In terms of gender differences in PA levels, the literature proposes that women are particularly less active and more sedentary than men (Corales et al., 2009; Lipošek et al., 2018; Majeric, 2016; Ng et al., 2009; Steptoe et al., 2002; Varela-Mato et al., 2012). Many academics suggest that women's health behaviours are more influenced by structural and psychosocial factors, such as stress, lower levels of self-esteem and sense of coherence, while men's health is more affected by health behaviours, such as smoking, drinking and PA (Denton et al., 2004; Valera-Mato et al., 2012).

Low levels of daily PA and excessive food consumption are associated with growing number of overweight and obesity among UCS (Kaj et al., 2015; Madureira et al., 2009; VarelaMato et al., 2012). For instance, Peltzer et al. (2014) assessed levels of overweight and obesity among UCS from 22 universities in low, middle income and emerging economy countries, and stated that among men $18.9 \%$ were overweight and $5.8 \%$ were obese, while $14.1 \%$ women were overweight and 5.2\% were obese. Similarly, high prevalence of overweight and obesity have been observed among UCS in Europe as well as in developing countries such as: Nigeria: 10\% (Nwachukwu et al., 2010), Egypt: 25.3\% (Abolfotouh et al., 2007), Mexico: 31.6\% (TrujilloHernández et al., 2010), and Turkey: 10\%-47.4\% (Rasim \& Erdem, 2013).

\section{Research Problem and Aim}

Reforms in higher education were expected to reinvent tertiary institutions, revise their objectives and tasks, and effectively improve the PA levels of academic youths (Muszkieta et al., 2019), since the purpose of higher education is to produce active and intellectually well-rounded individuals who possess the knowledge and skills for continued personal growth, including in the area of physical activity and health promotion. Nevertheless, literature indicates that universities are experiencing a physical inactivity crisis, and the recent generation of graduates is characterized by very low PA levels (e.g. Cardinal et al., 2012; Lipošek et al., 2018).

Consequently, the predominance of physical inactivity among UCS calls for immediate action (Corbin, 2002). However, academics suggest that individual will not change their PA behaviours simply at the request of others (Braithwaite et al., 2003; Keating et al., 2005) and therefore developing strategies for increasing PA behaviours among UCS population is even more crucial. The physical education and school sports (PESS) plays a key role in developing life-long lasting habits for active lifestyle (Haywood, 1991), which is particularly important among the first year students (Podstawski et al., 2014; Podstawski et al., 2013), and contributes to young people's development in four broad domains: physical, social, affective and cognitive (Bailey et al., 2009).

OF EDUCATION

IN THE $21^{\text {st }}$ CENTURY

Vol. 78, No. 6, 2020

1029 
Robert PODSTAWSKI, Krzysztof BORYSŁAWSKI, Marta ZURAWIK, Alena BUKOVA, Bojan MASANOVIC, Ferenc IHASZ, Miloš MARKOVIĆ, Aneta OMELAN. Influence of organisational factors on the implementation of physical education in European tertiary institutions

PROBLEMS

OF EDUCATION

IN THE $21^{\text {st }}$ CENTURY

Vol. 78, No. 6,2020

1030

Therefore, the purpose of this research was to analyse the influence of organisational factors on the implementation of PE in European higher education. Furthermore, this research also aimed to challenge the status of PE in tertiary institutions and recommend directions for a sustainable future of PE curricula in higher education.

\section{Research Methodology}

\section{General Background}

The research was designed to explore these issues by employing the quantitative methodology. A quantitative approach, using questionnaire, provides a numeric description of some fraction of a research population through asking questions, which enables a researcher to generalize the findings from a sample of responses to a population (Creswell, 1994: 117). Questionnaires are a suitable method for collecting data from research participants in an unobtrusive manner, whilst reducing researcher bias (Creswell 2009).

The strength of the quantitative approach lies in collecting structured quantifiable data from collection of institutions that are known to be representative. It allows researchers to feel confident about the representativeness of a sample for broader inferences by using a statistical sampling procedure. In addition, the quantitative method allows information to be measured and compared.

\section{Instrument and Procedures}

Research was carried out upon the prior consent of the Ethical Committee of the University of Warmia and Mazury in Olsztyn, Poland (No. 39/2011).

A purposive sampling method to recruit participants was employed, which involved selecting people to produce the most valuable data for the research purpose. Therefore, an invitation for a research collaboration was issued to all academics attending the $16^{\text {th }}$ Annual Scientific Conference of Montenegrin Sports Academy entitled: "Sport, Physical Activity and Health: Contemporary Perspectives" in Dubrovnik, Croatia. Furthermore, academic peers who worked in various European research and teaching centres were contacted via Researchgate. net platform. Forty-seven academics who agreed to participate in the study were required to answer all questions concerning PA programs from at least 10 European tertiary institutions by the end of February 2020. All respondents were informed that participation was voluntary, and withdrawal was allowed at any time.

In this research, anonymous and confidential questionnaires with 16 closed-ended questions and two open-ended questions were used. The questionnaire had the same set of written questions in a predetermined order concerning characteristics of tertiary institutions (size, profile, type, number of students, number of teachers/instructors), sport facilities (number, type, size), types of PA programs available for students (obligatory and facultative classes, extracurricular activities, paid activities), and characteristics of PA sessions (duration, number of students, teachers/instructors).

In total, out of forty-seven initial participants, only seven academic peers completed and returned the questionnaires. The participating academics collected information on 66 tertiary institutions hosting 798,181 students, located in Poland (30), Slovakia (12), Serbia (6), Hungary (6), Czech Republic (5), Slovenia, Turkey, Spain, Montenegro, Croatia, Bosnia \& Hercegovina, and Kosovo (1 in each country).

\section{Data Analysis}


Robert PODSTAWSKI, Krzysztof BORYSŁAWSKI, Marta ZURAWIK, Alena BUKOVA, Bojan MASANOVIC, Ferenc IHASZ, Miloš MARKOVIĆ, Aneta OMELAN. Influence of organisational factors on the implementation of physical education in European tertiary institutions

Overall, information was gathered from 66 European tertiary institutions. Data were analysed with emphasis on types of tertiary institutions (public vs private and universities vs other institutions). Data in the text are given as means \pm standard deviations. The differences between the means were analysed using the $t$-Student test for independent variables. The relationships between interval features were assessed by calculating the $r$-Pearson correlation coefficient. Statistical analyses were performed using Statistica $13.0 \mathrm{pl}$. Significance level was accepted at $p<.05$

\section{Research Results}

Pearson product-moment correlation coefficient was computed to assess the relation between the populations of cities and number of students in tertiary institutions. In general number of public and private tertiary institutions, including universities in cities, was not significantly correlated with the number of students. However, there was a significant correlation ( $r=.664, p=.011)$ between a number of other tertiary institutions, such as polytechnics, colleges, pedagogical high schools, higher vocational schools and art schools, and number of students.

There was a significant difference in the number of students $(p=.003)$ in public tertiary institutions $(14,294.3 \pm 13,913.6)$ in comparison to private ones $(1,091.3 \pm 1,323.9)$. Furthermore, public tertiary institutions had significantly higher number of PE hours per semester $(p=.023)$, PE sessions per semester (.019), number of minutes per academic hour $(p=.009)$, duration of PE session $(p=.011)$, number PE teachers $(p=.023)$ and number of students per one PE teacher $(p=.049)$ (Table 1).

\section{Table 1}

Characteristics of Public versus Private Tertiary Institutions

\begin{tabular}{lllll}
\hline \multirow{2}{*}{ Characteristics } & Public $(N=55)$ & Private $(N=11)$ & \multicolumn{2}{l}{ Difference } \\
\cline { 2 - 5 } & $M \pm S D$ & $M \pm S D$ & $t$ & $p$ \\
\hline City population [thousand] & $511.9 \pm 541.0$ & $421.5 \pm 438.8$ & 0.520 & $n s$ \\
No. of students & $14,294.3 \pm 13,913.6$ & $1,091.3 \pm 1,323.9$ & 3.125 & .003 \\
No. of PE semesters & $2.78 \pm 2.15$ & $2.46 \pm 3.39$ & 0.415 & $n s$ \\
No. of PE hours per semester & $26.22 \pm 8.40$ & $18.73 \pm 14.89$ & 2.337 & .023 \\
No. of PE hours during the studies & $60.49 \pm 40.08$ & $55.46 \pm 72.99$ & 0.326 & $n s$ \\
No. of PE sessions per semester & $13.87 \pm 5.28$ & $9.36 \pm 7.45$ & 2.406 & .019 \\
No. of minutes per academic hour & $42.45 \pm 13.94$ & $28.64 \pm 22.70$ & 2.676 & .009 \\
Duration of PE session [minutes] & $82.45 \pm 25.16$ & $57.27 \pm 45.41$ & 2.605 & .011 \\
No. of PE teachers & $13.53 \pm 10.57$ & $5.91 \pm 4.93$ & 2.329 & .023 \\
No. of students per PE teacher & $1,708.2 \pm 2,405.3$ & $326.5 \pm 403.8$ & 1.98 & .049 \\
\hline Note: $n s-$ no significant differences & & & &
\end{tabular}

There was a significant difference in the number of students $(p=.015)$ at universities $(1,4751.4 \pm 1,4753.1)$ than other institutions $(5,981.2 \pm 7,955.7)$. Moreover, universities had significantly higher number of PE semesters $(p=.047)$, minutes per academic hour $(p=.048)$, and hired more PE teachers $(p=.049)$ in comparison to other tertiary institutions (Table 2 ).

$\mid$\begin{tabular}{l} 
PROBLEMS \\
OF EDUCATION \\
IN THE 21 $1^{\text {st }}$ CENTURY \\
Vol. 78, No. 6, 2020 \\
\hline 1031
\end{tabular}


Robert PODSTAWSKI, Krzysztof BORYSŁAWSKI, Marta ZURAWIK, Alena BUKOVA, Bojan MASANOVIC, Ferenc IHASZ, Miloš MARKOVIĆ, Aneta OMELAN. Influence of organisational factors on the implementation of physical education in European tertiary institutions

PROBLEMS

OF EDUCATION IN THE $21^{\text {st }}$ CENTURY Vol. 78 , No. 6, 2020

1032

Table 2

Characteristics of Universities versus Other Tertiary Institutions

\begin{tabular}{lllll}
\hline \multirow{2}{*}{ Characteristics } & University $(N=46)$ & Other $(N=20)$ & \multicolumn{2}{l}{ Difference } \\
\cline { 2 - 5 } City population [thousand] & $M \pm S D$ & $M \pm S D$ & $t$ & $p$ \\
No. of students & $475.3 \pm 500.5$ & $546.6 \pm 583.1$ & 0.505 & $n s$ \\
No. of PE semesters & $14,751.4 \pm 14,753.1$ & $5,981.2 \pm 7,955.7$ & 2.498 & .015 \\
No. of PE hours per semester & $3.11 \pm 2.37$ & $1.85 \pm 2.18$ & 2.030 & .047 \\
No. of PE hours during the studies & $26.22 \pm 7.80$ & $22.10 \pm 13.70$ & 1.549 & $n s$ \\
No. of PE sessions per semester & $65.24 \pm 47.48$ & $46.80 \pm 42.33$ & 1.496 & $n s$ \\
No. of minutes per academic hour & $13.41 \pm 3.68$ & $12.45 \pm 9.25$ & 0.609 & $n s$ \\
Duration of PE session [minutes] & $42.61 \pm 13.61$ & $34.50 \pm 18.71$ & 1.986 & .048 \\
No. of PE teachers & $82.28 \pm 23.84$ & $69.00 \pm 41.41$ & 1.645 & $n s$ \\
No. of students per PE teacher & $13.85 \pm 10.77$ & $8.60 \pm 7.95$ & 1.975 & .049 \\
& $1,799.1 \pm 2,608.9$ & $739.3 \pm 710.5$ & 1.781 & $n s$ \\
\hline
\end{tabular}

Notes: ns - not significant differences

Number of PA programs ( $p=.046)$ and sport facilities $(p=.011)$ were significantly higher in public tertiary institutions (Table 3 ).

Table 3

Characteristics of Sport Facilities in Tertiary Institutions

\begin{tabular}{lllll}
\hline Characteristics & Public $(N=55)$ & Private $(N=11)$ & $t$ & $p$ \\
\hline No. of PA programs & $11.85 \pm 5.66$ & $8.27 \pm 3.04$ & 2.033 & .046 \\
No. of sports facilities & $14.40 \pm 11.19$ & $5.45 \pm 3.17$ & 2.614 & .011 \\
\hline & University $(N=46)$ & Other $(N=20)$ & & \\
\hline No. of PA programs & $11.93 \pm 5.34$ & $9.70 \pm 5.55$ & 1.544 & $n s$ \\
No. of sports facilities & $15.30 \pm 11.55$ & $7.40 \pm 6.20$ & 2.877 & .005 \\
\hline & $\leq 500$ thousand $(N=45)$ & $>500$ thousand $(N=21)$ & & \\
\hline No. of PA programs & $11.22 \pm 5.52$ & $11.33 \pm 5.47$ & 0.076 & $n s$ \\
No. of sports facilities & $13.47 \pm 12.01$ & $11.71 \pm 7.80$ & 0.610 & $n s$ \\
\hline
\end{tabular}

Notes: ns - not significant differences

Universities had a significantly higher number of sport facilities $(p=.005)$ than other institutions however, there were no significant differences between the number of PA programs available to university students and those in other types of higher education institutions. The city populations where tertiary institutions were based were significantly associated with the number of sport facilities or PA programs available to students.

\section{Discussion}

The results of this research indicated that the number of students in public tertiary institutions was significantly higher. These findings are supported by Education, Audio- 
Robert PODSTAWSKI, Krzysztof BORYSŁAWSKI, Marta ZURAWIK, Alena BUKOVA, Bojan MASANOVIC, Ferenc IHASZ, Miloš MARKOVIĆ, Aneta OMELAN. Influence of organisational factors on the implementation of physical education in European tertiary institutions

visual and Culture Executive Agency (EACEA, 2012) suggesting that in Central and Easter European countries, which more recently joined European Union (EU), more students attend public tertiary institutions, and therefore, in those countries the higher education is publicly provisioned and put a strain on public funding (EACEA, 2012).

The research showed that the numbers of students and PE teachers in surveyed public tertiary institutions were higher. Nevertheless, it is worth noticing that the majority of PE teachers in European higher education are not full-time permanent academic staff but tend to have a temporary employment contact (Podstawski, 2018). In addition, the criteria for hiring PE teachers in tertiary institutions are inadequate. Podstawski (2018) indicated that many PE teachers are in fact instructors, without sufficient professional knowledge or competences, who conduct PA programs in order to supplement their salaries. Correspondingly, Korpak (2005) noticed the similar trends in Western Europe (i.e. Germany, the Netherlands, Belgium, Italy and Sweden) than the Eastern bloc countries. This might mean that the countries that joined the European Union later started adopting similar economically oriented approach to PE.

Despite the staffing differences between public and private institutions, the numbers of PE semesters and PE hours during the studies were similar. Furthermore, no significant differences in number of PE semesters and hours were observed in other types of tertiary institutions, such as polytechnics, colleges, pedagogical high schools, higher vocational schools, art schools.

In terms of PA programs, the public establishments had significantly higher number of PE hours, sessions and minutes per 1 academic hour. These differences between public and private institutions might be explained by a lack of clear guidelines regarding PE curricula in higher education, and greater autonomy of the private tertiary institutions. Furthermore, the lack of compulsory PE in higher education is common in the United States and European countries, where elective PA programs tend to be of a recreational kind (Cardinal et al., 2012; Hardman, 2008; Lipošek et al., 2018). This situation was caused by educational reforms implemented by many European countries, which contributed to diminishing status of the PE in higher education (Valero \& Van Reenen, 2019). Furthermore, the status of PE in European countries is influenced by different factors, including local sports traditions and the popularity of different sports and types of PA. Nevertheless, the strong presence of general PE classes in higher education still seems surprising.

PA programs in higher education adhere to minimum requirements of the syllabi, regardless of the type of the institution which results in restricting total amounts of PE among the students' populations. Podstawski (2017) suggested that majority of tertiary establishments perceive $\mathrm{PE}$ as an inferior subject and often adhere to inconsistent guidelines regarding the type and total amount of PE in their curricula, and often do not support the assessment of specific PE goals (Derri et al., 2012).

The supporters of school-based PE curricula have argued that obligatory PE could, at least to some degree, prevent overweight and obesity among university students, enhance fitness and motor skills, as well as improve students' concentration and cognitive functioning (Obama, 2012; Tomporowski, 2003).

\section{Conclusions and Limitations}

Academics recognize the need to increase levels of PA among UCS in order to improve their health and encourage healthy lifestyle in the long turn. However, this research suggests that PE has been marginalized in tertiary education and requires substantial reorganization.

PA offers significant health benefits and PE curricula at all education levels could reduce levels of obesity and health risk associated with sedentary lifestyle. In order to improve the PA levels of students, PE curricula in higher education should be restructured and implemented to facilitate learning, as well as provide as ability to maintain active and healthy lives of students.

PROBLEMS

OF EDUCATION

IN THE $21^{\text {st }}$ CENTURY

Vol. 78 , No. 6,2020

1033 
Robert PODSTAWSKI, Krzysztof BORYSŁAWSKI, Marta ZURAWIK, Alena BUKOVA, Bojan MASANOVIC, Ferenc IHASZ, Miloš MARKOVIĆ, Aneta OMELAN. Influence of organisational factors on the implementation of physical education in European tertiary institutions

PROBLEMS

OF EDUCATION IN THE $21^{\text {st }}$ CENTURY Vol. 78, No. 6, 2020

1034

Furthermore, in order to increase levels of PA among students, PE classes become obligatory, and other PA programs should be free and accessible during the entire study program.

It is important that PE curricula are thoughtfully planned and executed by considering extended hours, appropriately qualified teachers and improved financing.

The present research study has several limitations that need to be acknowledged. Majority of the surveyed institutions were from the former Eastern Bloc countries, where obligatory PE classes had been strongly promoted during the Communist regime. Therefore, the presented findings could differ if all EU Member States were equally represented. Another limitation was rather small number of other tertiary institutions, such as polytechnics, colleges, pedagogical high schools, higher vocational schools, art schools in the study sample, and differences in the number of tertiary institutions in each surveyed country. However, it must be noted that this research study surveyed 66 European tertiary institutions with a combined student population of 798,181, which broadly covers the European academic community and presents valuable data.

\section{Conflict of interests}

The authors declare no conflict of interests

\section{References}

Abolfotouh, M. A., Bassiouni, F. A., Mounir, G. M., \& Fayyad, R. C. (2007). Health-related lifestyles and risk behaviours among students living in Alexandria University hostels. EMHJEastern Mediterranean Health Journal, 13(2), 376-391. https://applications.emro.who.int/ emhj/1302/13_2_2007_376_391.pdf

Ali, A. (2010). Developing the community: The role of universities and open and distance learning. International Journal of Applied Engineering Research, 13(9), 6700-6708. http://oasis.col.org/ handle/11599/1119

American College Health Association. (2007). Standards of practice for health promotion in higher education. Journal of American College Health, 55(6), 376. https://www.acha.org/documents/ resources/guidelines/ACHA_Standards_of_Practice_for_Health_Promotion_in_Higher_ Education_October2019.pdf

Bailey, R., Armour, K., Kirk, D., Jess, M., Pickup, I., Sandford, R., \& Education, B. P. (2009). The educational benefits claimed for physical education and school sport: An academic review. Research Papers in Education, 24(1), 1-27. https://doi.org/10.1080/02671520701809817

Braithwaite, R. E., McDaniel, L., \& Reed, J. A. (2003). Gender differences within stages of exercise change. California Association for Health, Physical Education, Recreation and Dance Journal, 66(2), 12-16. https:/www.ncbi.nlm.nih.gov/pmc/articles/PMC5033515/

Bray, S. R., \& Born, H. A. (2004). Transition to university and vigorous physical activity: Implications for health and psychological well-being. Journal of American College Health, 52(4), 181-188. https://doi.org/10.3200/JACH.52.4.181-188

Cardinal, B. J., Sorensen, S. D., \& Cardinal, M. K. (2012). Historical perspective and current status of the physical education graduation requirement at American 4-year colleges and universities. Research Quarterly for Exercise and Sport, 83(4), 503-512. https://doi.org/10.1080/02701367.2012.10599139

Cardinal, B. J., Sorensen, S. D., \& Cardinal, M. K. (2012). Historical perspective and current status of the physical education graduation requirements at American 4-years colleges and universities. Research Quarterly for Exercise and Sport, 83(4), 503-512. https://doi.org/1 0.1080/02701367.2012.10599139

Colarez, V., Franca, C., \& Gonzales, E. (2009). Health-differences behaviour in a sample of Brazilian college students: Sex differences. Cadernos de Saúde Pública, 25, 521-528. https://doi.org/10.1590/S0102-311X2009000300007

Corbin, C. B. (2002). Physical education as an agent of change. Quest, 54(3), 182-195. https://doi.org/10.1080/00336297.2002.10491773 
Robert PODSTAWSKI, Krzysztof BORYSŁAWSKI, Marta ZURAWIK, Alena BUKOVA, Bojan MASANOVIC, Ferenc IHASZ, Miloš MARKOVIĆ, Aneta OMELAN. Influence of organisational factors on the implementation of physical education in European tertiary institutions

Creswell, J. (1994). Research Design: Qualitative and quantitative approaches. Sage.

Creswell, J. (2009). Research Design: Qualitative, quantitative and mixed methods approaches (3 ${ }^{\text {rd }}$ Ed.). Sage.

Denton, M., Prus, S., \& Walters, V. (2004). Gender differences in health: A Canadian study of the psychosocial, structural and behavioural determinants of health. Social Science \& Medicine, 58, 2585-2600. https://doi.org/10.1016/j.socscimed.2003.09.008

Derri, V., Avgerinos, A., Emmanouilidou, K., \& Kioumourtzoglou, E. (2012). What do Greek physical education teachers know about elementary students' assessment? Journal of Human Sport and Exercise, 7(3), 658-670. https://doi.org/10.4100/jhse.2012.73.06

Education, A. Culture Executive Agency EACEA(2012). Key data on education in Europe 2012. Brussels: EACEA P9 Eurydice. https://ec.europa.eu/eurostat/documents/3217494/5741409/978-92-9201242-7-EN.PDF/d0dcb0da-5c52-4b33-becb-027f05e1651f

Fagaras, S. P., Radub, L. E., \& Vanvuc, G. (2015). The level of physical activity of university students. Procedia - Social and Behavioral Sciences, 197, 1454-1457. https://doi.org/10.1016/j.sbspro.2015.07.094

Garber, C. E., Blissmer, B., Deschenes, M. R., Franklin, B. A., Lamonte, M. J., Lee, I. M., Nieman, D. C., \& Swain, D. P (2011). American College of Sports Medicine. American College of Sports Medicine position stand. Quantity and quality of exercise for developing and maintaining cardiorespiratory, musculoskeletal, and neuromotor fitness in apparently healthy adults: Guidance for prescribing exercise. Medicine and Science in Sports and Exercise, 43(7), 133459. https://doi.org/10.1249/MSS.0b013e318213fefb

Hardman, K. (2008). Physical education in schools: A global perspective. Kinesiology, 40(1), 5-28.

Haase, A., Steptoe, A., Sallis, J. F., \& Wardle, J. (2004). Leisure-time physical activity in university students from 23 countries: Associations with health beliefs, risk awareness, and national economic development. Preventive Medicine, 39(1), 182-190. https://doi.org/10.1016/j.ypmed.2004.01.028

Haskell, W. L., Lee, I. M., Pate, R. R., Powell, K. E., Blair, S. N., Franklin, B. A., Macera, C. A., Heath, G. W., Thompson, P. D., \& Bauman, A. (2007). Physical activity and public health: Updated recommendation for adults from the American College of Sports Medicine and the American Heart Association. Medicine and Science in Sports and Exercise, 39(8), 1423-1434. https://doi.org/10.1161/CIRCULATIONAHA.107.185649

Haywood, K. M. (1991). The role of physical education in the development of active lifestyles. Research Quarterly for Exercise and Sport, 62(2), 151-156. https://doi.org/10.1080/02701367.1991.10608705

Hilland, T. A., Stratton, G., Vinson, D., \& Fairclough, S. (2009). The physical education predisposition scale: Preliminary development and validation. Journal of Sport Sciences, 27(14), 1555-1563. https://doi.org/10.1080/02640410903147513

Kaj, M., Tékus, É., Juhász, I., Stomp, K., \& Wilhelm, M. (2015). Changes in physical fitness of Hungarian college students in the last fifteen years. Acta Biologica Hungarica, 66(3), 270-281. https://doi.org/10.1556/018.66.2015.3.3

Keating, X. D., Guan, J., Piñero, J. C., \& Bridges, D. M. (2005). A meta-analysis of college students' physical activity behaviours. Journal of American College Health, 54(2), 116126. https://doi.org/10.3200/JACH.54.2.116-126

Kim, M. S., \& Cardinal, B. J. (2017). Why university students enrol in physical activity education courses? Differential effects of required versus elective institutional policies. International Journal of Sports and Physical Education, 3(3), 16-26. http://dx.doi.org/10.20431/2454-6380.0303003

Korpak, B. (2005). Wychowanie fizyczne studentów na uczelniach europejskich [Physical education of students at European universities]. In Hanusz, H. \& Korpak, B. (Eds.), Wychowanie fizyczne studentów. Przeżytek czy Konieczność [Physical education of students. Obsolete or necesity] (pp. 153-159) Akademicki Związek Sportowy Press.

Kwan, M. Y, Cairney, J., Faulkner, G. E., \& Pullenayegum, E. E. (2012). Physical activity and other healthrisk behaviours during the transition into early adulthood: A longitudinal cohort study. American Journal of Preventive Medicine, 42, 14-20. https://doi.org/10.1016/j.amepre.2011.08.026

Li, K. K., Cardinal, B. J., \& Settersten, R. A. (2009). A life-course perspective on physical activity promotion: Application and implication. Quest, 61, 336-352. https://health.oregonstate.edu/ sites/health.oregonstate.edu/files/hallie-ford/pdf/biblio/a-life-course-perspective-on-activitypromotion.pdf 
Robert PODSTAWSKI, Krzysztof BORYSŁAWSKI, Marta ZURAWIK, Alena BUKOVA, Bojan MASANOVIC, Ferenc IHASZ, Miloš MARKOVIĆ, Aneta OMELAN. Influence of organisational factors on the implementation of physical education in European tertiary institutions

PROBLEMS

OF EDUCATION IN THE $21^{\text {st }}$ CENTURY Vol. 78 , No. 6, 2020

1036

Lipošek, S., Planinšec, J., Leskošek, B., \& Pajtler, A. (2018). Physical activity of University students and its relation to physical fitness and academic success. Annales Kinesiologiae, 9(2), 89-104. https://doi.org/10.35469/ak.2018.171

Madureira, A. S., Corseuil, H. X., Pelegrini, A., \& Petroski, E. L. (2009). Association between stages of behaviour change related to physical activity and nutritional status in university students. Cadernos de Saude Publica, 25(10), 2139-2146. https://doi.org/10.1590/s0102-311x2009001000005

Majeric, M. (2016). Gender differences in popularity and engagement in sport activities among students. Sport Mont, 14(3), 31-35. http://oaji.net/articles/2017/1045-1502701390.pdf

Martínez-Lemos, R. I., Puig Ribera, A., \& García-García, O. (2014). Perceived barriers to physical activity and related factors in Spanish university students. Open Journal of Preventive Medicine, 4, 164-174. https://doi.org/10.4236/ojpm.2014.44022

Muszkieta, R., Napierała, M., Cieślicka, M., Żukov, W., Kozina, Z., Iermakov, S., \& Górny, M. (2019). The professional attitudes of teachers of physical education. Journal of Physical Education and Sport, 19(1), 92- 99. https://doi.org/10.7752/jpes.2019.s1014

Ng, S. W., Norton, E. C., \& Popkin, B. M. (2009). Why have physical activity levels declined among Chinese adults? Finding from the 1991-2006 China health and nutrition surveys. Sociology \& Science in Medicine, 68(7), 1305-1314. https://doi.org/ 10.1016/j.socscimed.2009.01.035

Nwachukwu, D. C., Nwagha, U., Obikili, E. N., Ejezie, F. E., Okwuosa, C. N., Nweke, M. L., \& Ezeh, C. O. (2010). Assessment of body mass index and blood pressure among university students in, Enugu, South East, Nigeria. Nigerian Journal of Medicine, 19(2), 148-152 https://doi.org/10.4314/njm.v19i2.56503

Obama, M. (2012). The First Lady speaks out. Vibrant, 28(50), 32-30.

Peltzer, K., Pengpid, S., Samuels, T., Özcan, N. K., Mantilla, C., Rahamefy, O. H., Wong, M. L., \& Gasparishvili, A. (2014). Prevalence of overweight/obesity and its associated factors among university students from 22 countries. International Journal of Environmental Research and Public Health, 11(7), 7425-7441. https://doi.org/10.3390/ijerph110707425

Podstawski, R. (2017). Kultura fizyczna polskich studentów [Physical education of Polish students]. Forum Akademickie, 2, 56-57.

Podstawski, R. (2018). Wychowanie fizyczne jako integralny składnik edukacji zdrowotnej w uczelniach wyższych [Physical education as an integral component of health education at universities]. In Bodasińska, A. Jaślikowska-Sadowska, T., \& Piech, K. (Eds.), Dylematy szkolnego wychowania fizycznego różnorodność szansa na podniesienie atrakcyjności szkolnych $i$ pozaszkolnych zajęć ruchowych [Dilemmas of school physical education - diversity as a chance to increase the attractiveness of school and extracurricular physical activities] (pp. 21-34). AWF im. J. Piłsudskiego w Warszawie.

Podstawski, R., Choszcz, D., Klimczak, J., Kolankowska, E., \& Żurek, P. (2014). Habits and attitudes of first-year female students at Warmia and Mazury University: A call for implementing health education programme at universities. Central European Journal of Public Health, 22(4), 229-238. https://doi.org/10.21101/cejph.a3975

Podstawski, R., Gromadziński, L., Gizińska, R., \& Skibniewska, K. (2013). Health-oriented attitudes and opinions of 1 st year students at the University of Warmia and Mazury in Olsztyn on the prophylaxis of health hazards (2005/2006). Polish Annals of Medicine, 20(1), 25-29. https://doi.org/10.1016/j.poamed.2013.02.005

Saelens, B. E., Sallis, J. F., \& Frank, L. D. (2003). Environmental correlates of walking and cycling: findings from the transportation, urban design, and planning literatures. Annals of Behavioral Medicine, 25(2), 80-91. https://doi.org/10.1207/S15324796ABM2502_03

Sigmundova, D., Chmelik, F., Sigmund, E., Feltlova, D., \& Fromel, K. (2013). Physical activity in the lifestyle of Czech university students: Meeting health recommendations, European Journal of Sport Science, 13(6), 744-750. https://doi.org/10.1080/17461391.2013.776638

Sparling, P. B., \& Snow, T. K. (2002). Physical activity patterns in recent college alumni. Research Quarterly for Exercise and Sport, 73, 200-205. https://doi.org/10.1080/02701367.2002.10609009

Steptoe, A., Wardle, J., Fuller, R., Holte, A., Justo, J., Sanderman, R., \& Wichstrøm, L. (1997). Leisure-time physical exercise: Prevalence, attitudinal correlates, and behavioral correlates among young Europeans from 21 countries. Preventive Medicine, 26(6), 845 854. https://doi.org/10.1006/pmed.1997.0224

Tomporowski, P. D. (2003). Cognitive and behavioral responses to acute exercise in youths: A review. Pediatric Exercise Science, 15, 348-359. https://doi.org/10.1007/s10648-007-9057-0

Trujillo-Hernández, B., Vásquez, C., Almanza-Silva, J. R., Jaramillo-Virgen, M. E., Mellin-Landa, T. E., Valle-Figueroa, O. B., Pérez-Ayala, R., Millán-Guerrero, R. O., Prieto-Díaz-Chávez, E., \& Newton-Sánchez, O. (2010). The frequency of risk factors associated with obesity and being overweight in university students from Colima, Mexico. Revista de Salud Pública, 12(2), 197207. https://doi.org/10.1590/s0124-00642010000200003 
Robert PODSTAWSKI, Krzysztof BORYSŁAWSKI, Marta ZURAWIK, Alena BUKOVA, Bojan MASANOVIC, Ferenc IHASZ, Miloš MARKOVIĆ, Aneta OMELAN. Influence of organisational factors on the implementation of physical education in European tertiary institutions

PROBLEMS

OF EDUCATION

IN THE $21^{\text {st }}$ CENTURY

Vol. 78, No. 6,2020

1037

Cite as: Podstawski, R., Boryslawski, K., Zurawik, M., Bukova, A., Masanovic, B., Ihasz, F., Markovič, M., \& Omelan, A. (2020). Influence of organisational factors on the implementation of physical education in European tertiary institutions. Problems of Education in the $21^{\text {st }}$ Century, 78(6), 1027-1037. https://doi.org/10.33225/pec/20.78.1027

\begin{tabular}{|c|c|}
\hline $\begin{array}{l}\text { Robert Podstawski } \\
\text { (Corresponding author) }\end{array}$ & $\begin{array}{l}\text { PhD, Lecturer, University of Warmia and Mazury in Olsztyn, Department } \\
\text { of Tourism, Recreation and Ecology, Oczapowskiego 5, 10-719 Olsztyn, } \\
\text { Poland. } \\
\text { E-mail: podstawskirobert@gmail.com } \\
\text { ORCID: https://orcid.org/0000-0002-1492-252X }\end{array}$ \\
\hline Krzysztof Borysławski & $\begin{array}{l}\text { PhD, Professor, Wrockaw University of Life and Environmental Sciences, } \\
\text { Department of Anthropology, ul. C. K. Norwida 25, 50-375 Wrockaw, } \\
\text { Poland. } \\
\text { E-mail: krzysztof.boryslawski@upwr.edu.pl } \\
\text { ORCID: htps://orcid.org/0000-0002-6290-1192 }\end{array}$ \\
\hline Marta Zurawik & $\begin{array}{l}\text { PhD, Independent Researcher, } 2 \text { Wilson Avenue, WN6 7HD Wigan, } \\
\text { United Kingdom. } \\
\text { E-mail: martazurawik@hotmail.com } \\
\text { ORCID: htps://orcid.org/0000-0002-4636-0373 }\end{array}$ \\
\hline Alena Bukova & $\begin{array}{l}\text { PhD, Special Assistant, Pavol Jozef Šafárik University in Košice, } \\
\text { Institute of Physical Education and Sport, Ondavská 21, } 04011 \text { Košice, } \\
\text { Slovak Republic } \\
\text { E-mail: alena.bukova@upjs.sk } \\
\text { ORCID: https://orcid.org/0000-0002-8470-0236 }\end{array}$ \\
\hline Bojan Masanovic & $\begin{array}{l}\text { PhD, Assistant Professor, University of Montenegro, Faculty for } \\
\text { Sport and Physical Education, Narodne omladine bb, } 81400 \text { Niksic, } \\
\text { Montenegro. } \\
\text { E-mail: bojan.masanovic@ucg.ac.me } \\
\text { ORCID: htps://orcid.org/0000-0002-4939-4982 }\end{array}$ \\
\hline Ferenc Ihasz & $\begin{array}{l}\text { Professor, Eötvös Lóránd University, Faculty of Psychology and } \\
\text { Pedagogy, Institute of Sports Sciences, Szombathely, Hungary. } \\
\text { E-mail: ihasz.ferenc@ppk.elte.hu } \\
\text { ORCID: https://orcid.org/0000-0003-0213-2237 }\end{array}$ \\
\hline Miloš Marković & $\begin{array}{l}\text { PhD, Assistant Professor, University of Belgrade, Faculty of Sport and } \\
\text { Physical Education, Blagoja Parovića 156, Belgrade, Serbia } \\
\text { E-mail: miloscj@gmail.com } \\
\text { ORCID: https://orcid.org/0000-0001-9150-0390 }\end{array}$ \\
\hline Aneta Omelan & $\begin{array}{l}\text { PhD, Assistant Professor, University of Warmia and Mazury in Olsztyn, } \\
\text { Department of Tourism, Recreation and Ecology, Oczapowskiego 5, 10- } \\
719 \text { Olsztyn, Poland. } \\
\text { E-mail: aneta.omelan@uwm.edu.pl } \\
\text { ORCID: htps://orcid.org/0000-0002-3495-8837 }\end{array}$ \\
\hline
\end{tabular}

